\title{
Note
}

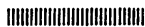

\section{Distribution of the Bound Form Tritium in the Whole Body of Brine Shrimps, Artemia salina, Reared in the Seawater Containing Tritiated Water ${ }^{\dagger}$}

\author{
Masataka HIGUCHI and Akiko MUKADE* \\ Laboratory for Radioisotopic Research, School of Medicine, Tohoku University, \\ Seiryo-machi, Sendai, 980, Japan \\ * Laboratory of Oceanography, Faculty of Agriculture, Tohoku University, \\ Amamiya-cho, Sendai 980, Japan \\ Received August 2, 1976
}

When organisms are administered tritiated water (THO), a considerable amount of tritium ( $T$ ) is retained in their dried tissue and presumably organic compounds in the tissue are universally labeled with $\mathrm{T}$.

We reported that brine shrimps, Artemia salina, reared in the seawater containing THO for a period of 5 days were labeled with $\mathrm{T}$ in their lyophilized tissue, up to the level of $\mathrm{T}$ content in the tissue corresponded to $30-50 \%$ of that in the seawater in terms of specific activity $(\mu \mathrm{Ci}$ of $\mathrm{T}$ per hydrogen atom), and also suggested that the radiation effect of THO to brine shrimp is severe on their reproductive capacity").

In this paper, we demonstrate the distribution of $\mathrm{T}$ in the whole body of $A$. salina, using the technique of autoradiography, and show that the bound form $\mathrm{T}$ might be concentrated in maturing eggs in either ovary or ovisac of the shrimps.

Dry eggs of $A$. salina (imported from Cosmo Enterprise Co. Ltd., Sanders, U.S.A.) were hatched and grown in filtrated natural seawater with and without THO ( $0.5 \mathrm{mCi}$ / $\mathrm{ml}$ ) at $20-25^{\circ} \mathrm{C}$.

Five nauplii (2-3 day old after hatching) were put into cylindrical glass vessels (2.5

†トリチウム含有海水で飼育したアルテミア体内で の結合性トリチウムの分布。桶口昌孝, 百足彰子： 東北大学医学部放射性同位元素研究室（仙台市星 陵町) $\mathrm{cm}$ in diameter) of $20 \mathrm{ml}$ capacity, containing $10 \mathrm{~m} l$ of seawater with and without 0.5 $\mathrm{mCi} / \mathrm{ml}$ THO. Every groups of the shrimps were reared and fed with about $50 \mathrm{mg}$ wet weight of diatoms at every weeks for 2 months. The diatom, Chaetoceros gracilis, were cultured in the Allen-Nelson's medium ${ }^{1)}$, which contains $0.4 \mathrm{~g}$ of $\mathrm{KNO}_{3}, 0.05 \mathrm{~g}$ of $\mathrm{Na}_{2} \mathrm{HPO}_{4} \cdot 12 \mathrm{H}_{2} \mathrm{O}: 0.08 \mathrm{~g}$ of $\mathrm{MgSO}_{4} \cdot 7 \mathrm{H}_{2} \mathrm{O}$, $0.026 \mathrm{~g}$ of $\mathrm{CaCl}_{2}$ and $5 \mathrm{mg}$ each of $\mathrm{FeCl}_{3}$ and sodium ethylenediamine-tetraacetate in $1 l$ of filtrated natural seawater without THO. The cells of diatom were harvested at the stationary phase and used for feeding the shrimps.

To prepare thin sections of $A$. salina for a autoradiography, the shrimps were fixed in the Carnoy's fluid, which consisted of ethanol and acetic acid (3:1). After dehydration with $70,80,90 \%$ ethanol and absolute ethanol successively, the serial longitudinal sections of the shrimps were made 5 micra at thickness through the ordinary paraffin method. The sections, which were fixed on slide glass were tightly contacted with X-ray film (Sakura, high speed, nonscreen, type $\mathrm{N}$ ), and were stored for 6 months at $4^{\circ} \mathrm{C}$.

When the sections of brine shrimps grown in seawater without THO were contacted with the film, we could not get any picture on the film. Thus, the autoradioograms in 
Fig. 1 and 3 show the $\mathrm{T}$ distribution in the dehydrated female shrimps, which were reared in THO seawater, indicating that rearing A. salina in THO seawater results in fundamentally universal labeling of the cell materials. However, the intensity of darkness in area of ovisac and/or eggs appeared to be higher than that of other areas of the sections. This is proved by scanning the autoradiogram, using a microdensitometer (Narumi, type NLM-7). As shown in Fig. 2, the light absorbancy in the ovisac is significantly higher than in other parts, suggesting that the $\mathrm{T}$ incorporation into organic materials from THO in this part might be brought about more actively. Fig. 3 shows an enlarged autoradiogram of the tail in the section of a young female brine shrimp. The autoradiogram demonstrates that the periphery of tail, where a few number of granules is present has higher intensity in darkness than the
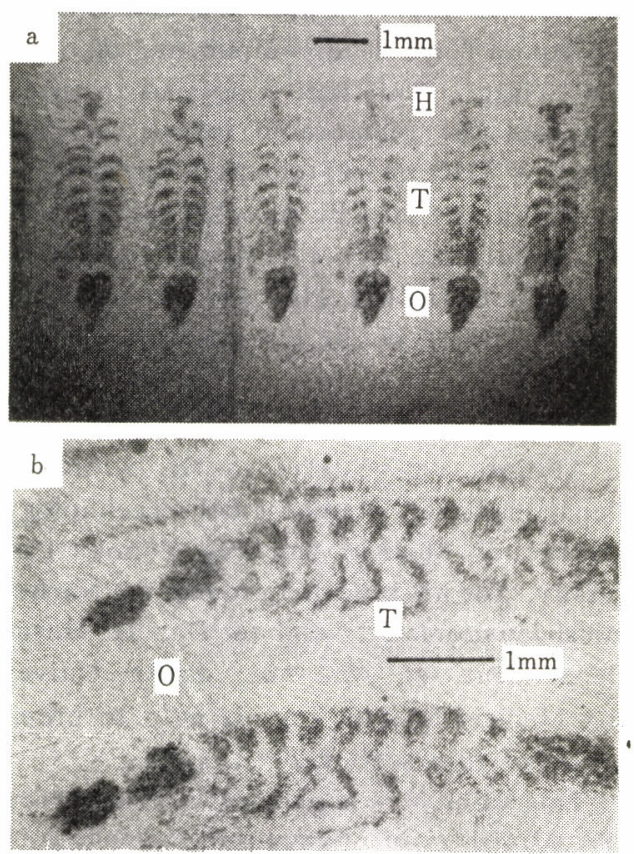

Fig. 1 Autoradiograms of the sections prepared from a whole body of female adult $A$. salina, which was reared in the seawater containing $0.5 \mathrm{mCi} / \mathrm{ml}$ THO for two months. a, Longitudinal cross section $(\times 10), b$, longitudinal lateral section $(\times 20)$. O: Ovisac, T: Trunk, H: Head.

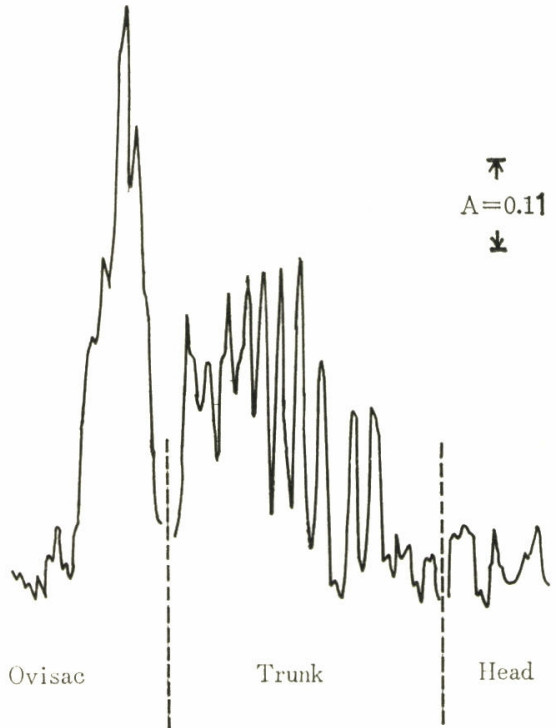

Fig. 2 Scanning of the autoradiogram of a longitudinal cross section prepared from a whole body of female adult A. salina, which was reared in 0.5 $\mathrm{mCi} / \mathrm{ml}$ THO-seawater for 2 months.

One of the autoradiograms shown in Fig. 1 a was scanned and recorded measuring light absorbancy automatically, by use of the Narumi microdensitometer (type NLM-7) with 0.1 $\mathrm{mm} \times 0.2 \mathrm{~mm}$ slit. The figure shows the respective patterns of the highest light absorbancy in the parts of head, trunk and ovisac in serial scannings, respectively.

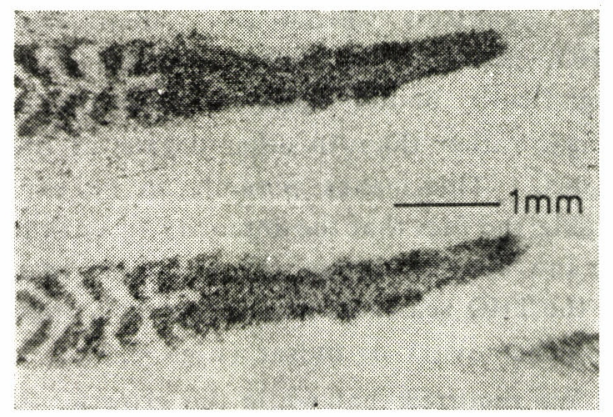

Fig. 3 Enlarged autoradiogram of the tail part in the section of a young female A. salina, reared in $0.5 \mathrm{mCi} / \mathrm{ml} \mathrm{THO}$ seawater.

inner part. The ovary of brine shrimp localizes in the peripheral part of the tail. Therefore, this suggests that ovary and/or immature eggs may incorporate $T$ from THO more than other tissues in the tail. 
Mechanism of the in vivo $\mathrm{T}$ labeling of cell materials with THO is mainly accounted for by the following two reactions: 1) Assimilation of $\mathrm{T}$ from THO through various biochemical synthesis, 2) the T-H exchange reaction between THO and $\mathrm{H}$ in organic compounds. Inomata \& Higuchi $(1976)^{7)}$ found that the rate of $T$ incorporation from THO into cell materials through the T-H exchange reaction in living cells of a heterotrophic photosynthetic bacterium, Rhodopseudomonas spheroides, appeared to be dependent on the bacterial cell metabolism even under non-growing conditions. In any event, the final extent of $T$ incorporation from THO into organic compounds in a tissue is dependent on the hydrogen (H) content in the tissue under the condition where THO is administered chronically. Because most organic compounds in organisms have similar $\mathrm{H}$ contents, as much as $5-6 \%$, it is reasonable to assume that $\mathrm{H}$ contents in dried tissues are proportional to the mass of the organic matters.

Eggs of Artemia contain not only germ cells, but also large amounts of nutrient substance which consist of various organic compounds $^{4}$. It is likely that these organic compounds are necessarily synthesized from T-labeled precursors and condensed in ovary and ovisac during the oogenesis in the organisms chronically administered THO, resulting in higher content of the organically bound form $T$ in ovary and ovisac rather than in other organs of organisms. This makes possible to be explainable the fact that the intensity of darkness on the autoradiogram of $A$. salina, reared in the THO seawater was remarkably higher in either ovary or ovisac (Figs. 1, 3).

We reported that while the growth rate, mortality and life span of Artemia salina grown in the seawater with $100 \mu \mathrm{Ci} / \mathrm{m} l$ THO were not affected, the reproductive capacity such as the average number of naupliis produced per pairing shrimps decreased significantly ${ }^{92}$.

Dobson and Cooper (1974) ${ }^{3)}$ reported that a significant decrease in number of female germ cells follows exposure of de- veloping mouse during gestation and suckling to maternally administered THO at levels in body water below $0.1 \mu \mathrm{Ci} / \mathrm{ml}$. The radiation dose calculated from the THO concentration is substantially below the level to cause measurable biological effects in mammals. Chronic administration of $10-100 \mu \mathrm{Ci} / \mathrm{m} l$ THO into pregrant rats also resulted in significant reduction of weights of testes, brain, and presumably ovaries in fetus, whereas no reduction of weight were noted in other organs in fetus ${ }^{2}$. Similar severe effects of THO on germ cells were observed in spermatogenesis in fish, Oryzia latipes $^{6}$.

In general, relative biological radiation effectiveness (RBE) of T- $\beta$ rays is estimated to be as much as $1-2.5), 8), 10,, 11$ ) The effect of chronic T-administration on reproductive organs seems to be more severe than the expectation from the RBE value of $T$.

In this paper, we showed that A. salina growing in the THO seawater concentrated the bound form $\mathrm{T}$ in components of ovary and ovisac. This fact tempts us to speculate that the remarkable severe radiation effect of THO on reproductive capacity of the organisms may be possibly attributable to not only the higher radiation sensitivity of germ cells, but also the accumulating bound form $\mathrm{T}$ in the reproductive organs.

\section{Acknowledgements}

Authors are grateful to Dr. S. Suzuki, Department of Radiological Technology, College of Medical Sciences, Tohoku University, for his kind help to use the Narumi microdensitometer, and to Dr. H. Hoshi, Department of Anatomy, Japan University Medical School, for his help to preparation of thin section of $A$. salina.

This work was supported by grants from the Ministry of Education, Science and Culture and also by aid from Japan Securities Scholarship Foundation.

\section{References}

1) Allen, E.J. and Nelson, E.W.: J. Marine Biol. Assoc. U.K., 8, 421 (1910) 
2) Cahill, D.F. and Yile, C.L.: Radiat. Res., 44, 727 (1970)

3) Dobson, L. and Cooper, M.F.: ibid., 58, 91 (1974)

4) Fautrez-Firlefyn, N.: Arch. Biol., 68, 249 (1957)

5) Hall, E.J., Oliver, R., Bedford, J.S.: Brit. J. Radiol., 40, 704 (1967)

6) Hyodo-Taguchi, Y. and Egami, N.: $J$. Radiat. Res., 15, 53 (1974)

7) Inomata, T. and Higuchi, M.: J. Bio- chem., 80, 569 (1976)

8) Johnson, H.A.: Tritium (Messenger Graphics, Phoenix, Arizona) p. 231 (1973)

9) Mukade, A. and Higuchi, M.: Bull. Plankton Soc. Japan, 21, 32 (1974)

10) Oliver, R.: Biological Effects of Transmutation and Decay of Incorporated Radioisotopes (International Atomic Energy Agency, Vienna) p. 165 (1968)

11) Vennart, J.: Health Phys., 14, 541 (1968) 